\title{
Antibacterial Properties of Polyester Fibres' Materials with Titanium Dioxide Deposited on Their Surface
}

\author{
I. KarbowniK ${ }^{a, *}$, D. KowalczyK ${ }^{a}$, G. Malinowska ${ }^{a}$ And B. PARUCH ${ }^{b}$ \\ ${ }^{a}$ Textile Research Institute, Gdańska 118, 90-520 Łódź, Poland \\ ${ }^{b}$ POCH S.A., Sowińskiego 11, 44-101 Gliwice, Poland
}

\begin{abstract}
$\mathrm{TiO}_{2}$ particles were deposited onto the surface of polyester (PES) material. The microbiological research were carried out on two bacteria strains: Staphylococcus aureus and Klebsiella pneumoniae, which showed antibacterial properties of the PES surfaces modified with the titanium dioxide under the influence of UV radiation.
\end{abstract}

PACS numbers: $61.80 . \mathrm{Ba}, 68.47 . \mathrm{Mn}, 81.07 . \mathrm{Wx}$

\section{Introduction}

$\mathrm{TiO}_{2}$ is commonly used in textile industry as a white colorant or a matting agent. The oxidizing or reductive properties of $\mathrm{TiO}_{2}$ under sunlight create new possibilities for its use as for giving the special features to the textile products. Under the influence of the absorbed UV light in semiconductor such as $\mathrm{TiO}_{2}$, electrons are knocked out from the valence band onto the conductive band. Thanks to that, on the surface of titanium dioxide, electrons $\left(\mathrm{e}^{-}\right)$ are created that combine with oxygen from the air creating active oxygen $\left(\mathrm{O}_{2}^{-\cdot}\right)$ and electron holes $\left(\mathrm{h}^{+}\right)$. Active oxygen releases reduction reactions, created electron holes are combined with water steam or with water, thus creating hydroxide radicals $\left({ }^{\circ} \mathrm{OH}\right)$. This process is similar to photosynthesis [1-3]. Professor Kazuhito Hashimoto from the Centre of Advances Technologies, Tokyo, draws our attention to three features of titanium dioxide, which make it exceptional among other substances with photocatalytic properties, and these are: high photocatalytic efficiency, great stability and low cost of production [4]. He points out that titanium dioxide is already a "tested" and safe material, known to people and used since the ancient times.

It should be noted that photocatalytic film also has antimicrobic properties, because the created radical very effectively prevent the development of microbes on the surface of the film and cause the deterioration of toxin produced by microbes. Because of that fact, photocatalytic films are used more and more often in hospitals, during the process of production of medical devices [5].

The aim of this work was to test the possibilities of deposition of titanium particles onto the surface of textile fabric and obtaining the antibacterial properties of the material modified in this way.

* corresponding author; e-mail: ikarbownik@iw.lodz.pl

\section{Methodology}

The following materials were used in the tests:

- $\mathrm{TiO}_{2}$ submicropowder of Degussa, under the trade name AEROXIDE ${ }^{\circledR} \mathrm{TiO}_{2} \mathrm{P} 25$ that was added to the polymer paste in the quantity of $5 \%$ as opposed to the dry polymer mass;

- $\mathrm{TiO}_{2}$ in aqueous dispersion produced by Nanopac under the trade name P\&T-230. P\&T-230 as aqueous solution includes $5 \%$ of titanium dioxide and silica in its volume;

- membrane creative polymers. From membrane creative polymers, aqueous dispersions of acrylic polymers were chosen to create polymer films;

- fabric was created from PES polyester fibres with surface mass $310 \pm 10 \mathrm{~g} / \mathrm{m}^{2}$.

A very important issue, connected with obtaining the assumed surface modification of the fabric, was to obtain an even, mononuclear dispersion of $\mathrm{TiO}_{2}$ on the surface of PES fabric and a $\mathrm{TiO}_{2}$ binding with its surface. In order to do so, a special method of titanium dioxide dispergation was used and for enhancing $\mathrm{TiO}_{2}$ adhesion a technique of treating the textile surface with cold plasma under the conditions of atmospheric pressure was used. Because of the general tendency of submicropowders to agglomerating, obtaining their stable suspension with mononuclear dispersion and sustaining this dispersion together with even placement of molecules in the polymer matrix is difficult. $\mathrm{TiO}_{2}$ submicropowders were created in the amount of acrylic polymer that was ten times higher than $\mathrm{TiO}_{2}$ and the solution was later treated with the active mechanic wave action for 15 min, obtaining mononuclear, homogeneous suspension of titanium dioxide. As a result of that, its mononuclear dispersion was obtained. The advantage of this method was elimination of any extra chemical agents (e.g. dispergers). 
PES fabric treating with cold plasma was carried out in the activator that generates corona discharge. The treatment of PES was carried out under conditions allowing modification of the top fibre layer without any damage to the fabric. Chemical and physical changes took place only on their top layer. In the research carried out in this case, the changes in adhesive properties obtained thanks to them were of great importance.

Modification technology of the PES fabric surface with titanium dioxide included:

— treating with cold plasma followed by coating,

— treating with cold plasma - impregnating (spraying).

Non-modified fabrics and fabrics that were modified on the surface with $\mathrm{TiO}_{2}$ later underwent the following tests:

- surface morphology done with the use of electronic scanning microscope JSM $35 \mathrm{C}$ of JEOL in high vacuum conditions,

- antibacterial properties, according to the norm ASTM E-2180 allowing the quantity evaluation of antibacterial activities of the analysed products.

Tests were carried out by Microbiological Laboratory of POCH S.A. in Gliwice. Two bacteria strains were used: Staphylococcus aureus ATCC 6538 and Klebsiella pneumoniae ATTC 4352. In the tests, it was assumed that the energy needed to induce a semiconductor such as $\mathrm{TiO}_{2}$ ranges from 3.0 to $3.2 \mathrm{eV}$, that is in order to cause antibacterial activity of the titanium dioxide, a radiation with the wavelength of below $400 \mathrm{~nm}$ would be necessary. Due to all that, in order to radiate the samples, a microbiological incubator equipped with a UV lamp emitting UV-A rays was used. The samples' exposition to UV-A rays was carried out for three hours. The bacteria strain reduction was evaluated in percentage, according to the equation

$\%$ of reduction $=(a-b) \times 100 / a$,

where $a$ - antilogarithm of geometrical average calculated for the reference sample, $b$ - antilogarithm of geometrical average calculated for a given tested sample,

geometrical average

$$
=\left(\log _{10} X_{1}+\log _{10} X_{2}+\log _{10} X_{3}\right) / 3,
$$

where $X-$ number $\mathrm{cfu} / \mathrm{ml}$ (cfu = colony forming unit) recovered from the given repetition $(1,2$ or 3$)$ of tested sample or the reference one.

\section{Results}

3.1. Reference to the state of the fabric surface

The looks of the polyester fabrics with and without $\mathrm{TiO}_{2}$ were illustrated in Figs. 1 and 2. The $\mathrm{TiO}_{2}$ additive introduced into the structure of the polymer film or added directly onto the surface of the fabric does not cause any visible change in its appearance in comparison with the appearance of the polymer film/fabric without $\mathrm{TiO}_{2}$ (Fig. 1 and 2).

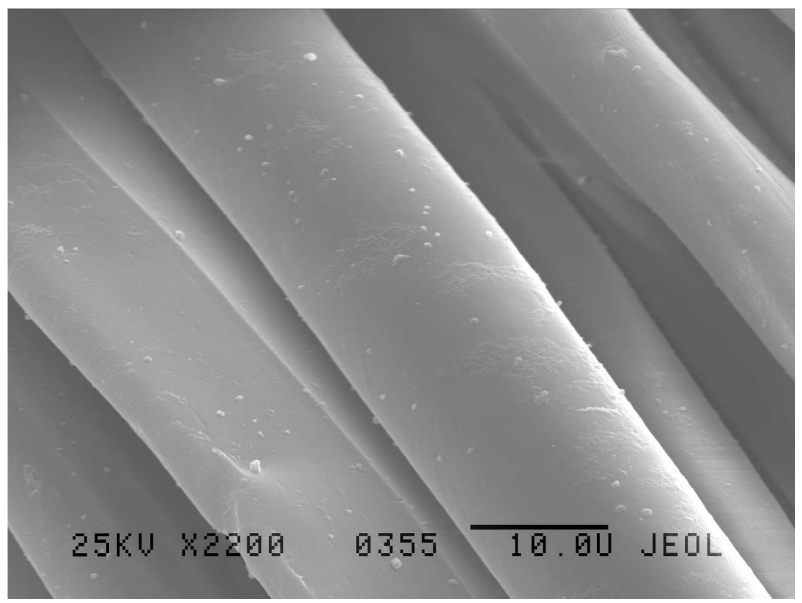

Fig. 1. Surface state of the PES fabric without $\mathrm{TiO}_{2}$.

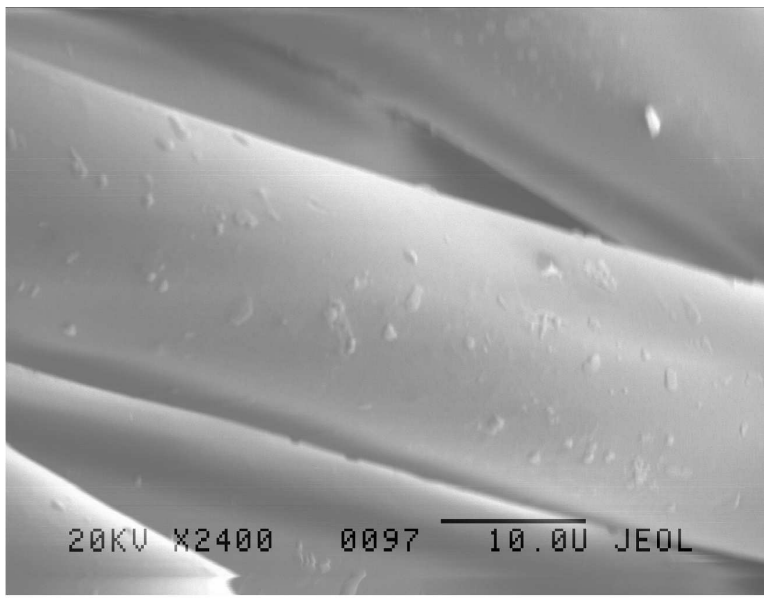

Fig. 2. Surface state of the PES fabric with $\mathrm{TiO}_{2}$.

\subsection{Reference to antibacterial properties' tests}

The results of the antibacterial tests of the samples after the washing were contrasted with Table.

From the tests presented in Table it can be seen that:

- fabrics with the acrylic polymer film (before and after washing), which include $\mathrm{TiO}_{2}$ in their structure show strong antiseptic activity,

- fabric onto a $\mathrm{TiO}_{2}$ film was sprayed (from Nanopac) showed for the samples after washing, that the bacteria strain reduction was at similar level. 
TABLE

Results of antibacterial tests for samples of fabrics that were non-modified/modified with $\mathrm{TiO}_{2}$ - after washing at $40^{\circ} \mathrm{C}$.

\begin{tabular}{|c|c|c|c|c|c|}
\hline \multirow[b]{2}{*}{ Sample number } & \multirow[b]{2}{*}{$\begin{array}{l}\text { Repetition } \\
\text { number } \\
(X)\end{array}$} & \multicolumn{2}{|c|}{ Staphylococcus aureus } & \multicolumn{2}{|c|}{ Klebsiella pneumoniae } \\
\hline & & $\begin{array}{l}\text { number } \mathrm{cfu} / \mathrm{ml} \\
\text { after contact } \\
\text { time }(3 \mathrm{~h})\end{array}$ & $\begin{array}{c}\% \\
\text { reduction }\end{array}$ & $\begin{array}{c}\text { number } \mathrm{cfu} / \mathrm{ml} \\
\text { after contact } \\
\text { time }(3 \mathrm{~h})\end{array}$ & $\begin{array}{c}\% \\
\text { reduction }\end{array}$ \\
\hline $\begin{array}{l}\text { PES fabric } \\
\text { sample }\end{array}$ & $\begin{array}{l}1 \\
2 \\
3\end{array}$ & $\begin{array}{c}58.5 \times 10^{1} \\
49.5 \times 10^{1} \\
54 \times 10^{1}\end{array}$ & - & $\begin{array}{c}24.5 \times 10^{2} \\
46 \times 10^{2} \\
37 \times 10^{2}\end{array}$ & - \\
\hline $\begin{array}{c}\text { PES fabric } \\
\text { sample with } \mathrm{TiO}_{2} \\
\text { (Nanopac) }\end{array}$ & $\begin{array}{l}1 \\
2 \\
3\end{array}$ & $\begin{array}{c}22.5 \times 10^{1} \\
36.5 \times 10^{1} \\
18 \times 10^{1}\end{array}$ & 54.4 & $\begin{array}{c}12.5 \times 10^{2} \\
10 \times 10^{2} \\
22 \times 10^{2}\end{array}$ & 59.6 \\
\hline $\begin{array}{c}\text { PES fabric sample } \\
\text { with the acrylic } \\
\text { polymer film }\end{array}$ & $\begin{array}{l}1 \\
2 \\
3\end{array}$ & $\begin{array}{c}95 \times 10^{1} \\
94.5 \times 10^{1} \\
-\end{array}$ & - & $\begin{array}{c}86 \times 10^{1} \\
100 \times 10^{1} \\
73.5 \times 10^{1}\end{array}$ & - \\
\hline $\begin{array}{c}\text { PES fabric sample } \\
\text { with acrylic polymer } \\
\text { and } \mathrm{TiO}_{2} \text { (Degussa) }\end{array}$ & $\begin{array}{l}1 \\
2 \\
3\end{array}$ & $\begin{array}{c}92.5 \\
59.5 \\
80\end{array}$ & 92 & $\begin{array}{l}54 \times 10^{1} \\
27 \times 10^{1} \\
47 \times 10^{1}\end{array}$ & 56.6 \\
\hline
\end{tabular}

\section{Discussion and conclusions}

Taking the above into consideration, household textiles (e.g. upholstery materials, curtains and decorative materials) made from materials finished with titanium dioxide with photocatalytic activity, can act as specific absorbers of bacterial pollution in rooms. Furthermore, as a result of photocatalytic dispersion, they can show activities of lowered cumulation of such pollution on their surface. This is the cause of slowing the processes of "getting dirty" of such surfaces, which prolongs the time needed between consecutive washings. In this way costs of product preservation is limited [6].

In the work it was presented that:

- tests of surface modification of fabrics with polyester fibres with titanium dioxide show a possibility of gaining bioactive activities,

- titanium dioxide placed in the polymer film on fabric's surface shows antibacterial properties under the influence of UV-A radiation.

\section{Acknowledgments}

The study was financial supported by the Polish Ministry of Science and Higher Education. The Project No. NN507 446034

\section{References}

[1] D. Quere, Langmuir 14, 2213 (1998).

[2] Home page Kazuhito Hashimoto: http://www.light.t.u-tokyo.ac.jp/ .

[3] P. Gould, Mater. Today 6, 44 (2003).

[4] K. Hashimoto, H. Irie, A. Fujishima, Jap. J. Appl. Phys. 44, 8269 (2005).

[5] K. Mori, Photocatalysis, J. Soc., Powder Technol. 41, 750 (2004).

[6] E. Lempa, Melliand Textilberichte 6, 459 (2005). 